\title{
Understanding of Chemical Pollution
}

Tran Phuong Nga, Phan Thi Kim Ngan, Mai Thanh Ngoc, Phan Thi Bao Ngoc, Nguyen

Thi Nguyen, Nguyen Y Nhi, Le Ngan Phuong, Nguyen Thu Phuong, Nguyen Minh

Quang, Ngo Viet Quan

Vietnam National University

Xuan Thuy, Cau Giay, Hanoi

January 23, 2022

Preprint DOI: $\underline{10.31219 / \text { osf.io/9qp5s }}$

The environment has long been the most important issue in the past or present and even in the future. Under the impact of innovation, people have great development in all special aspects built towards industrialization and modernization.

Human society is moving towards sustainable development, the transition and many problems that arise harmfully that are environmental pollution and especially chemical contamination due to waste of the technology industry that people think will completely replace human power. Without observation and concrete solutions, it will have serious consequences for the quality of human life and from there, people cannot move forward but are eroding life in the way that these toxic chemicals gnaw at our surroundings. This is also a dilemma for developing countries that want to break through into developed countries (Q.-H. Vuong, 2021).

The problem of chemical contamination is now at an alarming level, some say that the rate of human development is contrary to the development of the motherland. The reason why, in fact, the more people develop, the more inventions are invented, so that it exists and operates in need of a supply of energy. The growth of more such inventions brings many benefits but at the same time is also harmful to the environment if we do not know how to proceed. Moreover, the indiscriminate use of chemicals without 
knowledge is also one of the worrying current conditions, each chemical if used in a certain dosage will bring benefits, but if used to too high levels or the level can secrete toxins (the chemical itself already exists harmful substances) adversely affect the surrounding.

The cause of chemical contamination comes from many reasons. First of all, it's the cultural element. The culture mentioned here is environmental awareness, knowledge, attitude, action, and behavior (Khuc, Q.V., 2021; Q. H. Vuong, 2021; Q. H. et al. Vuong, 2018). Example, the units and people are not deeply aware of the indiscriminate use of chemicals as side effects such as toxins from pent-up chemicals, long-term storage causing serious consequences. Not only that, the geographical location is increasingly complex, appearing in small areas, zigzag causing difficulties in checking and extracting the names of chemicals, leading to difficulties in handling the remnants of pollutants. Moreover, the authorities loosely manage the use and storage of chemicals, the budget is insufficient for machinery, technology to handle pollutants, and lack of volunteers to help local authorities. In addition, for developing countries, chemical treatment lines and equipment are outdated, only average.

Chemical contamination has been having negative impacts, even having serious consequences for both the environment and human health. For the environment, fertilizers or wastewater can introduce chemicals containing nitrates or phosphates into the waters. The main food of algae is nitrates and phosphates. Overloading these chemicals will cause algae to bloom. When excess algae die and rot, dissolved oxygen is used up and the overall quality of the water is impaired. Therefore, aquatic creatures die from lack of oxygen. Even when long-term exposure to chemical pollutants causes native species in ecosystems to die, the region loses its diversity and becomes more vulnerable to invasive and undesirable species. In some cases, chemical pollution can kill populations of species that support ecosystems, such as bees. As for human health, due to frequent exposure to chemicals such as ambient air pollution, home air pollution, secondhand smoke and lead, "more than a third (35\%) of ischemic heart disease, the leading cause of death and disability worldwide, and about $42 \%$ of strokes, the second largest cause of global mortality." "Unintentional cases of poisoning are estimated to cause 193,000 deaths annually" with the majority due to exposure to toxic chemicals. Exposure to certain chemicals, such as lead, has been shown to be associated with 
reduced nervous system development in children and an increased risk of attention deficit disorder and intellectual disability, such as "Parkinson's disease that is associated with pesticide exposure." (Sở Y tế TP.HCM, 2018)

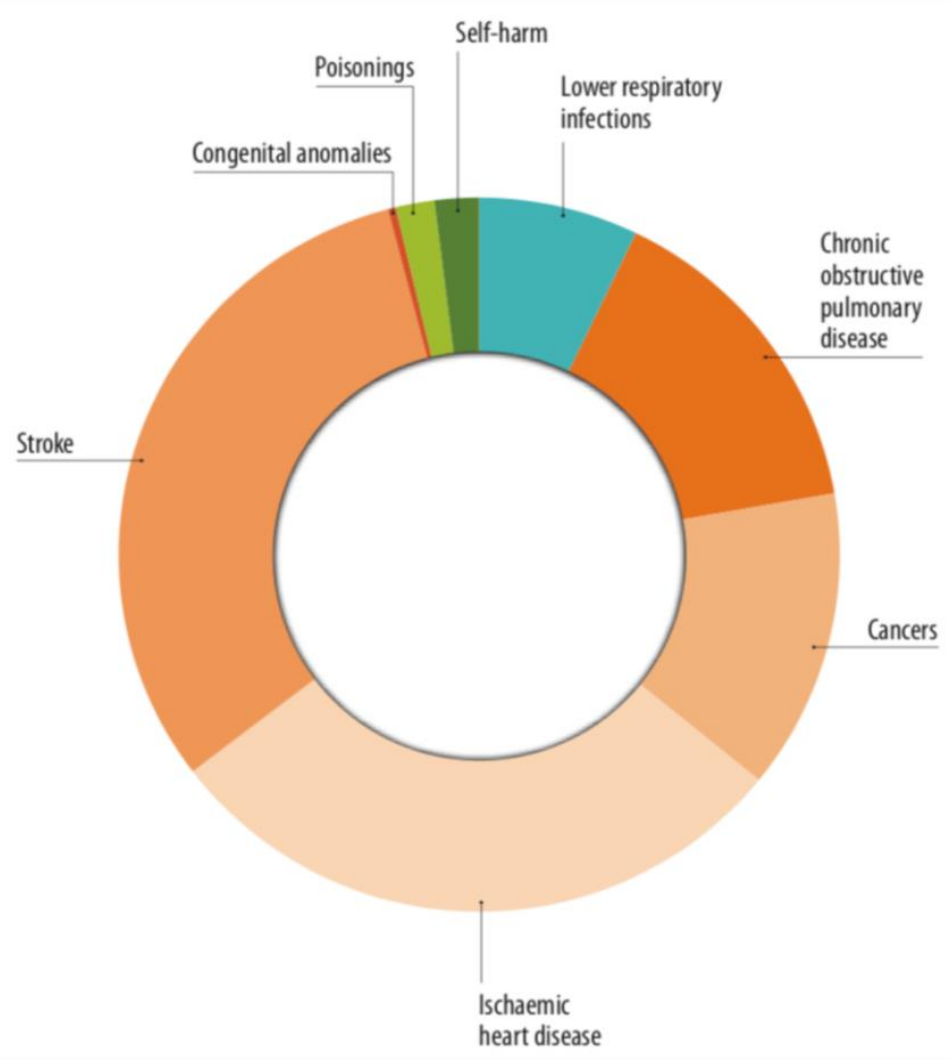

Figure 1: Distribution of mortality rates due to chemical-related pathological groups

Source: World Health Organization - 2016 
0.4

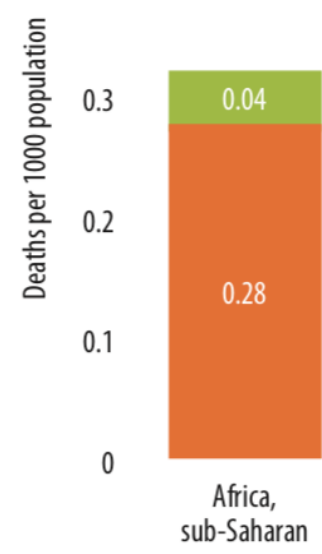

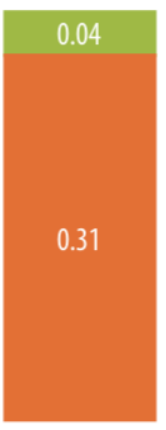

Eastern Mediterranean

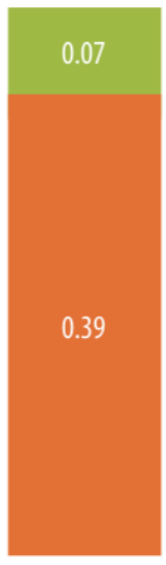

South-East Asia

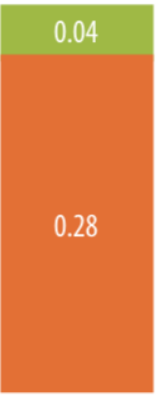

Western Pacific

Figure 2: Frequency of deaths from injuries and non-communicable diseases caused by exposure to toxic chemicals by regions of the world. Source: World Health Organization - 2016

To further demonstrate the serious effects of chemical contamination, here is a statistical analysis of chemical pollution in cities around the world along with the damage that chemical contamination has caused (BBT, 2007):

\begin{tabular}{|l|l|l|l|l|}
\hline \multicolumn{1}{|c|}{ City } & $\begin{array}{l}\text { Source of } \\
\text { pollution }\end{array}$ & Contaminants & $\begin{array}{l}\text { The number } \\
\text { of people at } \\
\text { risk of being } \\
\text { affected }\end{array}$ & \multicolumn{1}{|c|}{ Damage } \\
\hline Tianjin, China & $\begin{array}{l}\text { Mines and } \\
\text { processing } \\
\text { industry }\end{array}$ & $\begin{array}{l}\text { Lead and heavy } \\
\text { metals }\end{array}$ & $\begin{array}{l}140,000 \\
\text { people }\end{array}$ & $\begin{array}{l}\text { Reduce smart } \\
\text { index } \\
\text { Lead levels } \\
\text { increased } 24 \\
\text { times }\end{array}$ \\
\hline $\begin{array}{l}\text { Sukinda, } \\
\text { India }\end{array}$ & $\begin{array}{l}\text { Chromium } \\
\text { and } \\
\text { processing }\end{array}$ & $\begin{array}{l}\text { Chromium } \\
\text { chemotherapy } \\
\text { six and other } \\
\text { industry }\end{array}$ & $\begin{array}{l}\text { metals } \\
\text { people }\end{array}$ & $\begin{array}{l}60 \% \text { water } \\
\text { contaminated } \\
\text { with chromium } \\
84.7 \% \text { of deaths }\end{array}$ \\
\hline
\end{tabular}




\begin{tabular}{|c|c|c|c|c|}
\hline & & & & $\begin{array}{l}\text { are caused by } \\
\text { chromium } \\
\text { disease }\end{array}$ \\
\hline $\begin{array}{l}\text { La Oraya, } \\
\text { Peru higher } \\
\text { than the } \\
\text { permissible } \\
\text { limit. }\end{array}$ & $\begin{array}{l}\text { Heavy metal } \\
\text { mines and } \\
\text { processing } \\
\text { facilities }\end{array}$ & $\begin{array}{l}\text { Lead, copper, } \\
\text { zinc and sulfur } \\
\text { dioxide }\end{array}$ & 35,000 people & $\begin{array}{l}99 \% \text { of children } \\
\text { have lead levels } \\
\text { contaminated into } \\
\text { the blood. } \\
\text { The average lead } \\
\text { content is three } \\
\text { times }\end{array}$ \\
\hline $\begin{array}{l}\text { Dzerzhinsk, } \\
\text { Russia }\end{array}$ & $\begin{array}{l}\text { The } \\
\text { production } \\
\text { of chemical } \\
\text { weapons } \\
\text { since the } \\
\text { Cold War }\end{array}$ & $\begin{array}{l}\text { Toxic chemicals } \\
\text { and byproducts, } \\
\text { including sarin } \\
\text { and VX gas }\end{array}$ & $\begin{array}{l}300,000 \\
\text { people }\end{array}$ & $\begin{array}{l}\text { Contaminated } \\
\text { with dioxin and } \\
\text { phenol are } 17 \\
\text { million times } \\
\text { higher than safe } \\
\text { levels } \\
\text { In } 2003 \text {, the city's } \\
\text { death rate was } \\
260 \% \text { higher than } \\
\text { the birth rate. }\end{array}$ \\
\hline $\begin{array}{l}\text { Chernobyl, } \\
\text { Ukraine }\end{array}$ & Radioactive & Radioactive & $\begin{array}{l}5.5 \text { million } \\
\text { people }\end{array}$ & $\begin{array}{l}\text { No-go zone has a } \\
\text { radius of } 30 \mathrm{~km} \\
\text { around the plant } \\
\text { Getting thyroid } \\
\text { cancer while } \\
\text { living in the area }\end{array}$ \\
\hline $\begin{array}{l}\text { Sumgayit, } \\
\text { Azerbaijan }\end{array}$ & $\begin{array}{l}\text { Industrial } \\
\text { and } \\
\text { Petrochemic } \\
\text { al } \\
\text { ComplexEs }\end{array}$ & $\begin{array}{l}\text { Organic } \\
\text { chemicals, oil } \\
\text { and metals } \\
\text { weighing. }\end{array}$ & $\begin{array}{l}275,000 \\
\text { people }\end{array}$ & $\begin{array}{l}\text { The operating } \\
\text { plants that } \\
\text { discharge } \\
120,000 \text { tons of } \\
\text { toxic substances } \\
\text { have closed }\end{array}$ \\
\hline
\end{tabular}




\begin{tabular}{|l|l|l|l|l|}
\hline & & & & $\begin{array}{l}\text { Pollutants still } \\
\text { exist }\end{array}$ \\
\hline $\begin{array}{l}\text { Kabwe, } \\
\text { Zambia }\end{array}$ & $\begin{array}{l}\text { The } \\
\text { extraction } \\
\text { and } \\
\text { processing } \\
\text { of lead }\end{array}$ & $\begin{array}{l}\text { Lead and } \\
\text { cadmium }\end{array}$ & $\begin{array}{l}255,000 \\
\text { people }\end{array}$ & $\begin{array}{l}\text { The level of lead } \\
\text { present in the } \\
\text { blood of children } \\
\text { here is 5-10 times } \\
\text { higher than }\end{array}$ \\
& & & \begin{tabular}{l} 
acceptable levels. \\
\hline
\end{tabular}
\end{tabular}

* Images of chemical pollution: Images of chemical bottles thrown indiscriminately after being used on grass, water sources are heavily polluted by improper discharge plants:

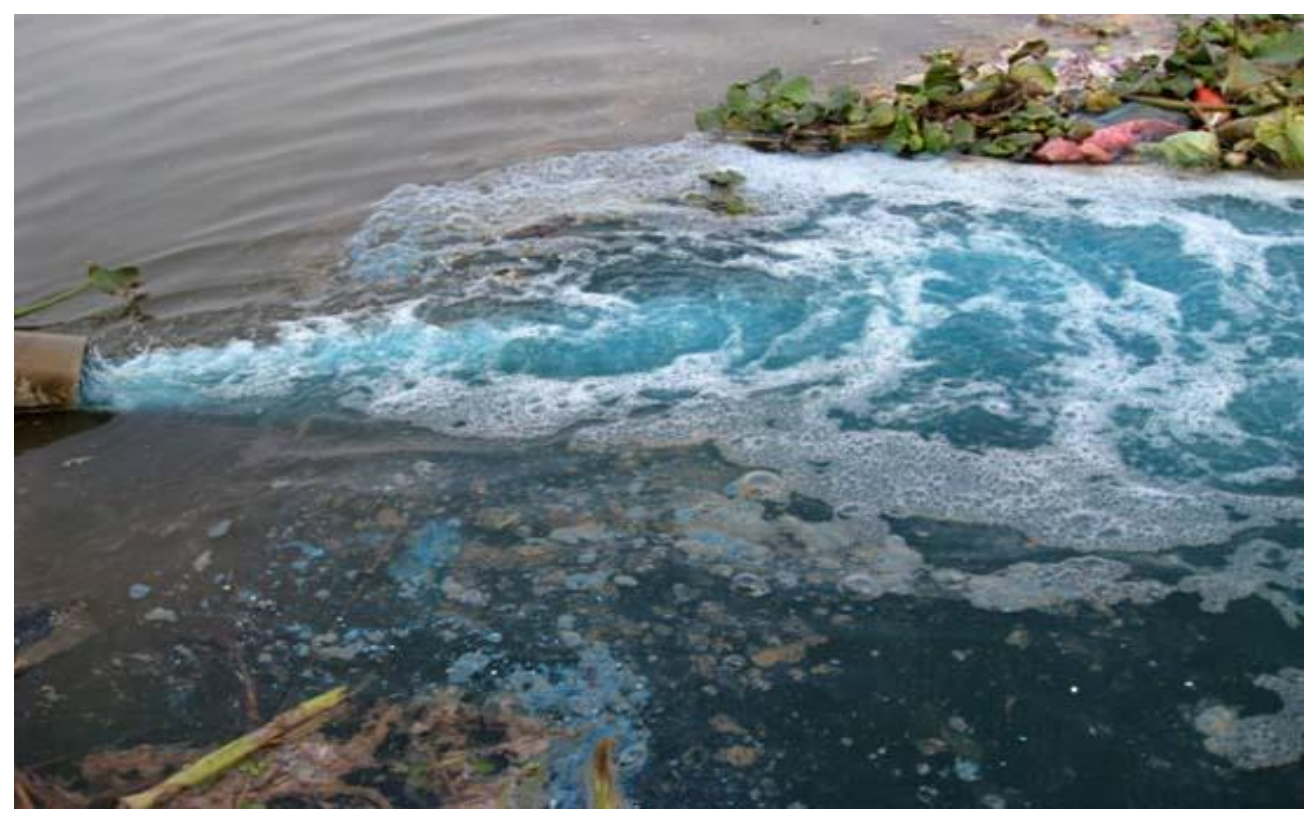

Figure 3: Images of water pollution caused by chemical discharges from factories

Source: Sports \& Culture Electronic Newspaper - VNA 


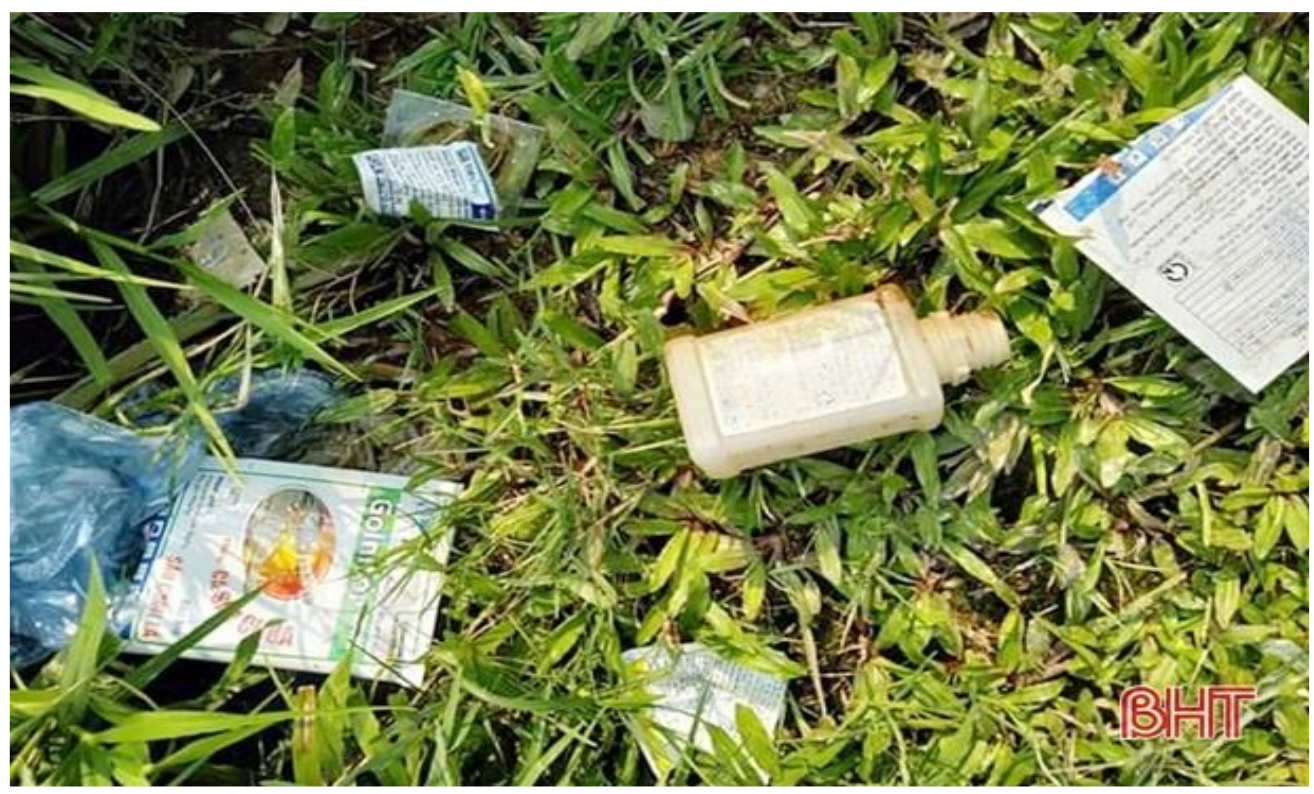

Figure 4: Pesticide packaging is dumped indiscriminately in the fields

Source: Ha Tinh Newspaper

It can be said that the ability to fully recover from a chemical contamination disaster is impossible because chemicals often penetrate deeply and have changed the structure of things that make it infected and difficult to eliminate. Therefore, in the face of the incalculable harm caused by chemical contamination, people need to take urgent measures to reduce and move towards eliminating chemical contamination.

Governments as well as organizations around the world have been making great efforts to come up with solutions and policies to limit and reduce chemical contamination. Many conventions have been signed, many projects have been implemented, not to mention some of the following conventions and projects: The Stockholm Convention on Persistent Organic Pollutants (May 22, 2001) aims to eliminate the production, use and emission of POP substances while preventing the introduction of new chemicals with POP-like properties and ensuring environmental rational destruction of POP waste reserves; The Minamata Convention on Mercury (January 9, 2013) is a global treaty aimed at protecting human health and the environment due to the harmful effects of mercury; The Rotterdam Convention (February 24, 2004) details import and export procedures for certain industrial chemicals and toxic pesticides; Basel Convention (05/05/1992) aims to reduce the arising of hazardous waste; encourage the disposal of hazardous waste near the source of the generating source, reduce the movement of 
these substances across borders and ensure that waste is best managed to protect the environment; The Global Environment Fund (GEF) plays a catalytic role in leveraging budgets from governments and encouraging the private sector to contribute more to achieving the elimination and mitigation of toxic chemicals and wastes; The China Chemical Safety Project (2012-2014) was implemented by the EU-funded IPEN, together with Czech and Chinese non-governmental partners, Arnika and Green Beagle, to raise awareness regarding emissions, chemicals, and strengthen the capacity of civil society organizations and communities affected by chemical contamination in China.

In order to reduce or solve the problem of chemical pollution in Vietnam, a number of solutions have been implemented in recent years. First of all, companies and businesses now pay attention to choosing less polluting technology to meet Vietnam's environmental requirements. A number of measures have been taken to reduce chemical pollution such as: building a system for collecting and treating wastewater, emissions, solid waste; in agricultural areas and rural populations: it is recommended that people use chemicals in agricultural production, gradually progressing to the development of clean agriculture; in areas where many trees are vacant, reasonable care should be taken, limiting the use of chemicals; to build a drainage and domestic wastewater treatment system as proposed for planning and domestic wastewater after treatment must reach QCVN 14:2008/BTNMT before discharging into the receiving source; reduce greenhouse gas emissions through the development of public transport networks with clean energy vehicles such as trams, etc. Reduce personal transportation. In particular, the waste and wastewater collection system of Van Dien Molten Fertilizer company also reduced coal consumption norms by $24 \%$, electricity by $20 \%$, thoroughly addressing waste dust and toxic components; Hebei Fertilizer and Chemicals Company has also researched the design of the system of treatment of xy-a-nua, H2S (sulphuine) in the gas-washing circulating wastewater at the coal gasification workshop, perfecting the technology of amolypus recovery in production wastewater (Bộ, 2014).

Although governments as well as environmental organizations have many policies and solutions proposed, there are still shortcomings in overcoming chemical contamination. International treaties and voluntary documents have minimized the risks of certain chemicals and waste, but progress has been uneven and still flawed in the 
implementation process. As of 2018, more than 120 countries have not implemented the Global Harmonization System for Chemical Classification and Labeling (UNEP Document Repository, 2019). In relation to the Stockholm Convention on Persistent Organic Pollutants, there has been some criticism of the convention as forcing the convention to be responsible for the continued employment of malaria-borne deaths from the use of DDT to control mosquitoes.

Chemical pollution is a global problem. Toxic chemicals are found in all ecosystems on Earth, thus affecting biodiversity, agricultural production and water environments. The chemical will be regenerated or discharged as part of the waste at the end of the life cycle. Improper management of such wastes adversely affects human health and the environment. Thus, in the face of the current chemical pollution, governments together with organizations around the world need to continue to issue appropriate and effective policies and solutions, including 3D information processing systems and valuable semiconductor principles to respond to this situation (Khuc, 2022; Q.-H. Vuong, 2021; Q. Vuong et al., 2022; Q. H. Vuong \& Napier, 2014).

\section{REFERENCES}

BBT. (2007). Mười thành phố ô nhiễm nhất thế giới. Báo Nhân Dân. https://nhandan.vn/tin-tuc-the-gioi/muoi-thanh-pho-o-nhiem-nhat-the-gioi-439940/

Bộ, P. N. (2014). Kiểm soát và giảm ô nhiễm trong ngành hóa chất. Báo Nhân Dân. https://nhandan.vn/tin-tuc-kinh-te/kiem-soat-va-giam-o-nhiem-trong-nganh-hoachat-202891/

Khuc, Q.V., et al. (2021). Understanding vietnamese farmers' perception toward forest importance and perceived willingness-to-participate in redd+ program: A case study in nghe an province. Forests, 12(5), 1-14. https://doi.org/10.3390/f12050521

Khuc, Q. Van. (2022). Về khả năng ứng dụng của hệ xử lý thông tin 3D và nguyên lý bán dẫn giá trị trong tìm kiếm giải pháp cho vấn đề ô nhiễm môi trường và biến đổi khí hậu ở Việt Nam. Tạp Chí Kinh Tế và Dự Báo, 1-5. https://kinhtevadubao.vn/ve-kha-nang-ung-dung-cua-he-xu-ly-thong-tin-3d-vanguyen-ly-ban-dan-gia-tri-trong-tim-kiem-giai-phap-cho-van-de-o-nhiem-moitruong-va-bien-doi-khi-hau-o-viet-nam-20840.html

Sở Y tế TP.HCM. (2018). Hoá chất và tác động lên sức khoẻ con người: những điều đã biết và chưa biết. Cổng Thông Tin Điện Tử Ngành Y Tế TP.HCM.

UNEP Document Repository. (2019). Triển vọng hóa chất toàn cầu II từ kế thừa đến các giải pháp sáng tạo.

Vuong, Q.-H. (2021). Western monopoly of climate science is creating an eco-deficit culture. Economy, Land \& Climate Insight, 11, 1-9. https://elc-insight.org/westernmonopoly-of-climat 
Vuong, Q. H. (2021). The semiconducting principle of monetary and environmental values exchange. Economics and Business Letters, 10(3), 284-290. https://doi.org/10.17811/ebl.10.3.2021.284-290

Vuong, Q. H. et al. (2018). Cultural additivity: behavioural insights from the interaction of Confucianism, Buddhism and Taoism in folktales. Palgrave Communications, 4(143). https://doi.org/10.1057/s41599-018-0189-2

Vuong, Q. H., \& Napier, N. K. (2014). Making creativity: the value of multiple filters in the innovation process. International Journal of Transitions and Innovation Systems, 3(4), 294-327. https://doi.org/10.1504/ijtis.2014.068306

Vuong, Q. H., et al. (2022). Covid-19 vaccines production and societal immunization under the serendipity-mindsponge-3D knowledge management theory and conceptual framework. Humanities and Social Sciences Communications, 9, 22. Retrieved from: https://www.nature.com/articles/s41599-022-01034-6 